
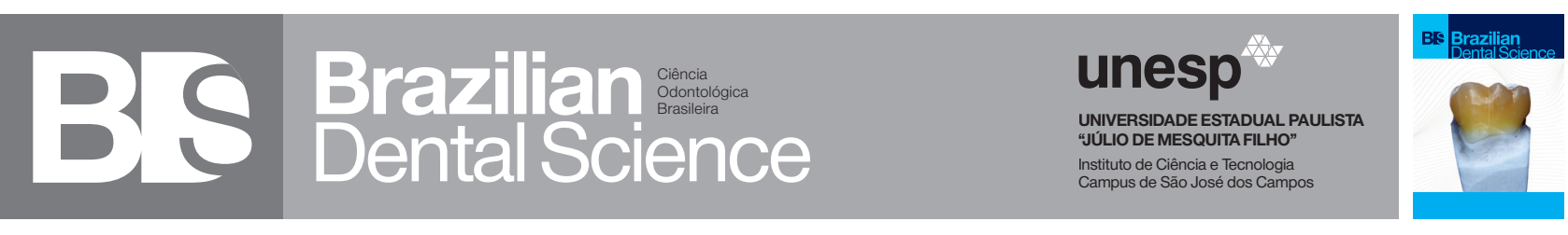

\title{
Deciduous tooth early loss prevalence in posterior region and indication of band-loop space maintainer
}

Prevalência da perda precoce de dente decíduo na região posterior e indicação de mantenedor de espaço banda-alça

Ana de Lourdes Sá de LIRA ${ }^{1}$, Ageu Lima da COSTA ${ }^{1}$, Guilherme Henrique Alves da FONSECA ${ }^{1}$, Nayra Rafaelle Fernandes da SILVA ${ }^{1}$, Keila Rejane de Jesus MARTINS ${ }^{1}$

1 - Universidade Estadual do Piauí - UESPI - School of Dentistry - Department of Pediatric Dentistry and Orthodontics - Area of Integrated Clinic - Parnaíba - PI - Brazil.

\begin{abstract}
Objective: To investigate the prevalence of the early unitary loss of deciduous and the need for space maintainer in the posterior region, of the band-loop type. Material and Methods: The clinical examination by two examiners of 568 children between 6 and 12 years of age in mixed dentition was performed in two municipal schools. After the diagnosis of premature loss of one or two deciduous molars (unilateral, one or both arches, respectively), without successors initiating the eruptive process in the oral cavity, the child was referred to the Clinical School of Dentistry (CSD) of State University of Piauí (UESPI) for installation of the band-handle space maintainer. Results: The prevalence of early deciduos molar loss was $4.04 \%$, from 568 children examined, being 15 in the lower arch and 8 in the upper arch of 23 children, mean age of $10 \pm 2$ years with predominance of the first deciduos molars (10 in the lower arch and all 8 in the upper arch). The etiological factor of which was dental caries for all sample, according to the parents or guardians. Only 13 attended the CSD for detailed examination. After radiographic examination, it was verified that 8 did not need space maintainers because they were approximately $2 / 3$ of the permanent successors root formation. In 5 children was placed the maintainer of space, band-handle, who are being supervised every 3 months until the eruption of the permanent successors. Conclusion: The prevalence of early molar loss was $4.04 \%$ with no statistical difference between genders. The use of space maintainers after the early loss of a deciduous tooth is a preventive measure of malocclusion, being the band-loop appliance an excellent choice after loss of the deciduous unilateral molar.
\end{abstract}

\section{KEYWORDS}

Space maintainer; Mixed dentition; Preventive orthodontics.

\section{RESUMO}

Objetivo: Investigar a prevalência a perda precoce unitária de decíduo e a necessidade de mantenedor de espaço na região posterior do tipo banda-alça. Material e Métodos: O exame clínico realizado por dois examinadores de 568 crianças de 6 a 12 anos de idade na dentição mista foi realizado em duas escolas municipais. Após o diagnóstico de perda precoce de um ou dois molares decíduos (unilateral, de uma ou ambas arcadas, respectivamente), sem que os sucessores tivessem iniciando o processo eruptivo na cavidade bucal, a criança foi encaminhada à Clínica Escola de odontologia (CEO) da Universidade Estadual do Piauí (UESPI) para instalação do mantenedor de espaço banda-alça. Resultados: A prevalência da perda precoce de molar decíduo foi de $4.04 \%$, de 568 crianças examinadas, sendo 15 na arcada inferior e 8 na arcada superior de 23 crianças, com idade média de $10 \pm 2$ anos com predomínio dos primeiros molares decíduos (10 no arco inferior e todos os 8 no arco superior). O fator etiológico foi cárie dentária para toda a amostra, segundo os pais ou responsáveis.Somente 13 compareceram à CEO para exame detalhado. Após exame radiográfico constatou-se que 8 não precisavam de mantenedores de espaço pois estavam aproximadamente com $2 / 3$ de formação radicular dos sucessores permanentes. Em 5 crianças colocou-se o mantenedor de espaço, bandaalça, que estão sendo supervisionadas a cada 3 meses até a erupção dos sucessores permanentes. Conclusão: A prevalência da perda precoce de molar decíduo foi de $4.04 \%$ sem diferença estatística entre os gêneros. O uso de mantedores de espaço após a perda precoce de dente decíduo é uma medida preventiva da má oclusão, sendo a banda-alça excelente opção após a perda do molar decíduo unilateral.

\section{PALAVRAS-CHAVE}

Mantenedor de espaço; Dentição mista; Ortodontia preventiva. 


\section{INTRODUCTION}

$\mathrm{T}$ he deciduous dentition is important for the growth and development of the dental arches, jaws and muscles of the face, as well as for the breathing and harmony of facial aesthetics. These factors emphasize the importance of maintaining it until the normal time of exfoliation [1,2].

In Brazil, children have a high rate of dental extraction without adequate space maintenance. These occur mainly due to the presence of extensive caries lesions, causing discomfort, pain and limitations to the individual who is affected [3-5].

The premature loss of deciduous molars determines the early eruption of permanent teeth if it occurs in a period close to its normal exfoliation and delay in the eruption period of its successors if it occurs at a time very early to that of its normal exfoliation. This is because at the site of loss there is new bone formation on the dental germ, in addition to fibrosis in the gingival tissue due to the trauma caused by chewing of food [6].

In view of the early loss of a deciduous tooth, it is important to install a space maintainer in order to avoid harmful repercussions on the normal development of occlusion, which can lead to future occlusal problems such as arch shortening, mesial inclination of the first molar and impaction of the second premolar or upper canines, accompanied by tooth turning, supraeruption of the opposing teeth and impairment of the future periodontal support [7].

The main etiologic factor of malocclusion in the permanent dentition is the early dental loss in the deciduous or mixed dentition, which could be avoided with the use of space maintainers. The band loop is indicated when there is unilateral loss of first or second deciduous molar [2].
Whenever a deciduous tooth is lost before the time where it should occur under normal conditions, the reduction or arc length is a consequence, therefore, predisposes the patient to a malocclusion. In these cases, this problem presents the need to preserve the space for the tooth substitute, so we should put a space maintainer [8-10].

The justification for this research was to investigate the occurrence of early unitary loss of deciduous molar during mixed dentition in public school students, considering the difficulty of access to dental treatment in the Family Health Strategy in Public Health Politics, since there are still families without care coverage or situations in which the supply of dental care is lower than the demand for it.

Since early loss of the deciduous dentition is associated with several morphofunctional problems, and the use of maintainers may help in the treatment of these problems, this research aimed to investigate the prevalence of early deciduous unit loss and the need for a space maintainer in the posterior region of the bandloose type.

\section{METHOD}

This study was approved by the Research Ethics Committee of the State University of Piauí - CEP / UESPI, under the opinion number: 1.643.861. It was a cross-sectional, quantitative, intervention study. The sample calculation was based on the target population: children between 6 and 12 years enrolled, specifically in the school phase, of the city of Parnaíba in 2017, totalizing 5.087 students. The sample was nonprobabilistic, and after the sample calculation it should be $\mathrm{n}=578$, but it was composed of 568 children, since 10 of them did not want or were not allowed to participate in the research. This minimum number of participants is considered sufficient considering the proposed analyzes, 
the sampling error of $5 \%$, and a $95 \%$ confidence level, indicating that the probability of the mistake made by the survey does not exceed 5\%.

The inclusion criteria were children during the mixed dentition, in the age group of 6 to 12 years, of both genders, students of the Elementary School: San Francisco of Capuchinhos School (School 1) and Municipal School Caio Passos (School 2), both in the municipality of Parnaíba, Piauí, whose parents or guardians and children had accepted the research, with the consent form signed, and as exclusion criteria: children who were not in the mixed dentition and children with special needs.

These two schools were chosen because they presented a large number of students in the age group of the research and being that in school 1 the teaching was in the two shifts and to 2 only in the morning shift. The researchers suspected that such a difference could influence the prevalence of early loss of deciduous molars.

The oral examination was first performed in schools to verify if there was a loss of deciduous molar in each hemi-arcade in a room reserved under natural light, using gloves of procedures and wooden spatula and later in Clinical School of Dentistry (CSD) of the State University of Piauí, after scheduling with parents or guardians, when dental loss was found.

The two researchers were calibrated in the CSD to determine if tooth loss was early or not, taking into account whether or not the space was closed, which may occur after tooth loss, or if there was bone covering the germ of the permanent, since its absence accelerates the eruption itself and the stage of development of the germ of the permanent, presenting great eruptive potential when it meets $2 / 3$ of root formed [1].

The calibration exercise was performed with 20 children not participating in the research in a municipal school, according to a methodology described in another publication
[11]. Subsequently, the pilot study involving 45 students was carried out with the objective of testing the proposed methodology. As a result, its viability was observed, without adjustments. In order to measure intra- and inter-examiner diagnostic reproducibility, $10 \%$ of the total sample was double-checked by each of the examiners, with the Kappa coefficient for intraand inter-examiner agreement being 0.99 and 0.98 , respectively.

During clinical care in the CSD, cases of deciduos molar loss in each hemi-arcade, investigating the etiology that could be due to caries, hypomineralization of the enamel or other etiological factor, were recorded in the odontogram, Periapical radiographs were taken in the regions of the arcade where the dental loss occurred, to verify the presence of the permanent successor, its level of root formation, and if there was no loss of space for them, by the mesial inclination of the first permanent molars.

The researchers performed preventive orthodontic treatment using the selection and adaptation of the orthodontic bands in the permanent molars for the preparation of the band-loop appliance. The bands were selected and adapted to the molars. Alginate molding and subsequent transfer of the band to the molding were done, and the working model was cast with type II gypsum.

The appliance was made with $0.20 \mathrm{~mm}$ orthodontic wire in the working model. Subsequently, the band was welded to the wire in its middle third. Then the apparatus was removed from the model and finished with stone mounted and polished with Spain White in the welding region $[7,8]$. In the following session he was cemented with glass ionomer Fuji Ortho Band (Japan) in the CSD, after a previous appointment with the parents or guardians.

Regarding the use of the space maintainer, a series of requirements were obeyed, according to the literature, which consisted of: 
maintaining the desired interproximal space without interfering with the occlusion of the opposing teeth nor with the eruption of the permanent tooth; allow sufficient mesiodistal space for permanent tooth alignment to erupt; do not change in phonetics and chewing and, if possible, re-establish these functions and also present a simple design and be easy to hygiene [12].

The space maintainer used in this research, band-loop, is classified as fixed and functional, unilateral, adapted to a band on an intact abutment tooth. The loop should be satisfactorily broad enough to allow eruption of the permanent successor tooth without the need for removal of the appliance, and should also be close to the mucosa without pressing it (Figure 1) $[12,13]$.

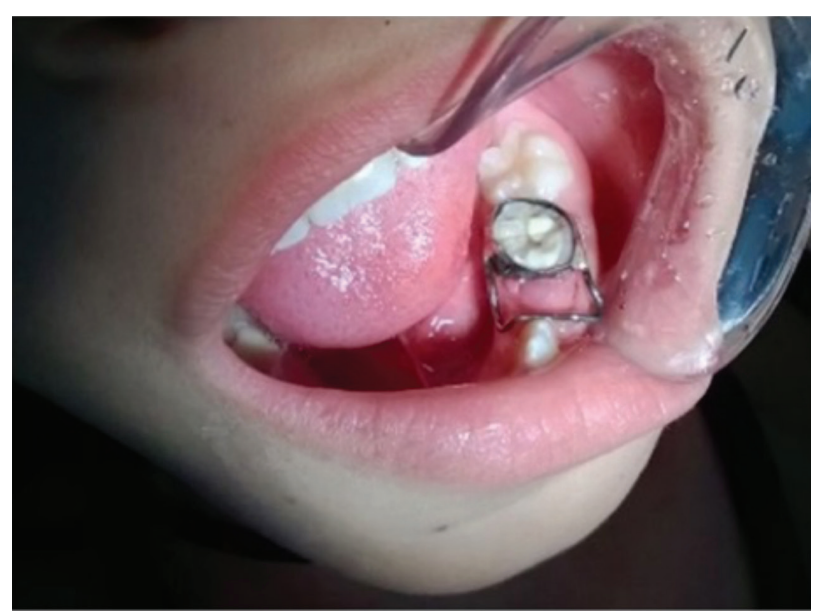

Figure 1 - Band-loop maintainer installed.

Lectures on oral hygiene and eating habits were offered to the parents or caregivers in the school environment, contributing to the improvement and promotion of health. Children who have had other dental necessities, such as dental caries, gingivitis and malocclusion were referred for dental treatment in the CSD.

Every three months, after the placement of the maintainer, the same children have been supervised in the CSD to verify the conditions of the appliance, preservation of the dental space or confirmation of the time of removal, which will coincide with the eruption of the permanent successor.

The statistical package SPSS, in its version 21 , was used to calculate the measures of central tendency, proportion, percentages and dispersion, in order to characterize the sample. With this same software, the degree of association of prevalence between genders and dental arch was obtained through the Chisquare test in the two different schools.

\section{RESULTS}

The prevalence of early deciduos molar loss was $4.04 \%$, from 568 children examined, being 15 in the lower arch and 8 in the upper arch of 23 children, mean age and standard deviation of $10 \pm 2$ years with predominance of the first deciduos molars (10 in the lower arch and all 8 in the upper arch) and there was no statistical difference when the schools were analyzed separately. The etiological factor of which was dental caries for all sample, according to the parents or guardians, although there is a possibility of molar loss due to second or primary molar hypomineralization.

Of the 568 children examined, 160 studied at school 1, $88(55 \%)$ of the male gender and 72 (45\%) of the female gender; and 408 in school 2, of which $213(52.2 \%)$ were males and 195 (47.8\%) were females. At school 1, only 10 had unitary tooth loss in the posterior region, 8 in the lower arch and 2 in the upper arch; while in school 2, thirteen presented dental losses in the posterior region, 6 in the upper arch and 7 in the lower arch (Figure 2). 


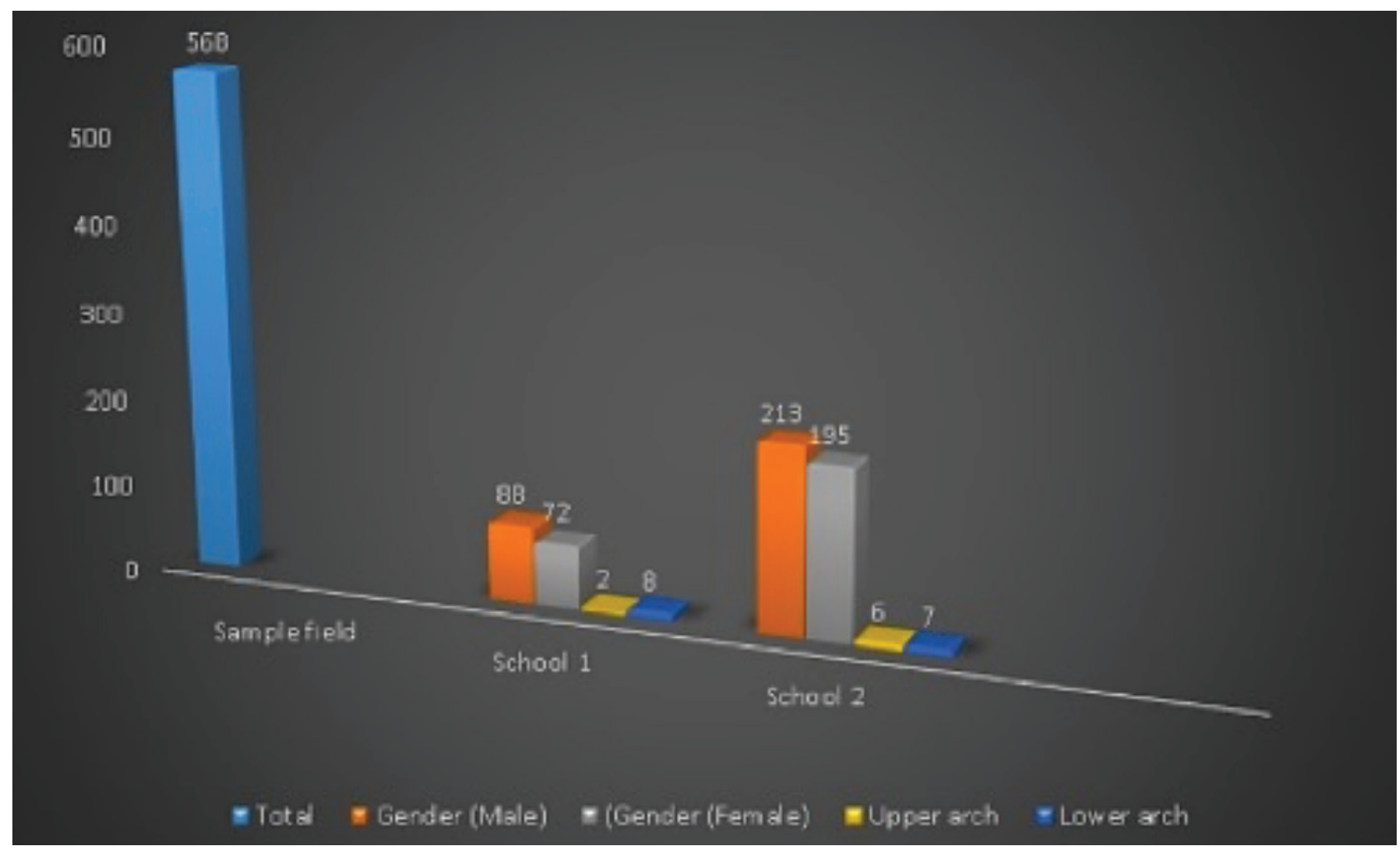

Figure 2 - Distribution of the sample examined and of the arches with unitary dental losses.

Of the 10 children previously selected in school 1, only 6 attended the CSD. After radiographic examination, it was found that 4 did not require space maintainers because they had $2 / 3$ root formation of the permanent successors (stage 8 of Nolla) [1], and was placed in only two of them. Regarding school 2, out of 13 children, only 7 came to the CSD. After radiographic examination, it was found that 4 did not need space maintainers, for the same reason as for school children 1, and the band was placed in only 3 of them.

At school 1, 55\% $(\mathrm{n}=88)$ were male and $45 \%(\mathrm{n}=72)$ female (Figure 1$)$. As a result of the statistical calculation $X^{2}$ (Chi-square), $X^{2}(1)$ $=0.400, p=0.53$, it was verified that there was no statistically significant difference between the genders of the participants at 5\% level of significance.

When analyzing the prevalence of tooth loss, it was observed that $80 \%(\mathrm{n}=8)$ was lower and 20\% (n = 2) higher, and that this difference was statistically significant $X^{2}(1)=3,600, p$ $<0.05$. Therefore, in School 1, the prevalence did not differ in the gender of the participants, but in the dental arcade, although an equitable distribution was expected (Figure 2)

These same procedures and tests were performed in school 2 , in which a prevalence rate of only $3.18 \%$ was observed, that is, 13 children out of 408 . These 13 were represented by $76.9 \%$ $(\mathrm{n}=10)$ girls and $23.07 \%(\mathrm{n}=3)$ boys. It was observed $\times 2(1)=3,769, \mathrm{p}<0.05$, and there was a statistically significant difference between the genders of the participants, considering a significance level of $5 \%$. The girls, in fact, differed from the expected and were the most affected.

The $X^{2}(1)=0.077$ test, $p=0.78$, showed that there was no statistically significant difference between the arches. Thus, in school 2 , prevalence differed with respect to gender, since an equitable distribution was expected. The data of the children who placed the band maintainer were shown in Table 1. 
Table 1 - Data from children who placed the band-handle

\begin{tabular}{|cccc|}
\hline & Gender & Age & Early deciduous tooth \\
\hline Case 1 & Male & 12 & First molar upper left \\
\hline Case2 & Female & 10 & First molar lower left \\
\hline Case 3 & Male & 9 & First molar upper left \\
\hline Case 4 & Female & 11 & First molar lower right \\
\hline Case 5 & Male & 10 & Second molar lower right \\
\hline
\end{tabular}

Foot note: Parnaíba- Pl. 2018.

\section{DISCUSSION}

Early losses of deciduous teeth have often been studied because of their relevance and association with occlusion abnormality, so that in the mixed phase, space maintainers are used to maintain the space corresponding to the permanent successor tooth. The loss of arch length resulting from this process can lead to the development of several malocclusions in the permanent dentition [9,10,15-17]

The loss of a deciduous tooth is considered to be early or premature when it occurs at least one year before its normal exfoliation or after radiographic evidence that the permanent successor is still short of Nolla stage 6, that is, with coronary formation and root formation not yet started $[3,5,7]$.

Several studies have been published regarding the premature loss of deciduous teeth [5,7-10,14-17]. However, according to Owen [18], there is a great diversity of opinions about the clinical consequences of premature loss of deciduous teeth, especially regarding the need to use space maintainers.

The molar loss was expected to be higher due to the population presenting a caries experience and second or primary molar hypomineralization. However the prevalence of early molar loss in this study was lower than that observed in other studies [9,10,15-17]. In the study by Cardoso et al [15], the prevalence was $54.62 \%$, being $49.15 \%$ in the male gender and $50.84 \%$ in the female.
According to the findings of Cardoso et al. [9], the second lower deciduous molars are the most affected teeth, diverging from our findings. Already in the studies Kuramae et al. [13] and Galindo et al. [14] the first molar was more affected than the second corroborating this study.

It was verified that the etiological factor of the early loss of deciduous molars was dental caries, corroborating the findings of Souza et al. [16] when affirming that in Brazil, it plays a predominant role, due to socioeconomic problems and lack of knowledge of those responsible for paper of primary teeth, since treatment is often neglected. Although the possibility of dental loss should be considered due to the hypomineralization of the deciduous molars, since this pathology does not affect only the incisors and molars, but also the primary molars, which may evolve to the development of carious lesion and consequently the loss according to the literature [18].

Based in previous studies the authors defend the need for placement of space maintainers have pointed out that the premature loss of deciduous teeth negatively impacts the permanent dentition in development and may result in a greater number of dental crowding or loss of space during the transition between the deciduous and permanent dentition, corroborating countless authors $[1,5,7,8,13$ 17,19].

For KorytnickI et al. [12] the main consequences of premature loss are the migrations of the adjacent teeth to the originated space. Almeida et al. [1] considered that any early extraction of deciduous second molars could interfere the occlusion of the first permanent molars, since they are guided by the distal face of the second deciduous molar to adequately occlude the antagonist.

According to Pokorná et al. [20] some considerations must be observed by the dental surgeon when evaluating the possibility and necessity of space maintenance, such as: the type of malocclusion that the patient presents; 
presence or absence of space in the dental arch; time elapsed after loss; amount of bone on the unbroken crown of the tooth; sequence of dental eruption and congenital absence of the permanent successor.

In the case of premature loss, a detailed clinical evaluation, in addition to the complementary radiographic examination, should be performed before beginning the treatment to observe the presence of the permanent successor tooth, its stage of development and the amount of bone covering it, O. In addition, it is essential to analyze the models in cases of patients with deciduous or mixed dentition [1,20-23].

The band-loop, which is a non-funtional fixed space maintainer indicated for noncollaborative patients, in cases in which the early loss is, preferably unilateral and the space is not very extensive, mainly of the first and second deciduous molars [17].

As contraindications, patients with sensitivity to metallic materials and with loss of more than one tooth. As advantages can be cited the easy hygienization and confection, presented, good resistance and low cost, besides not dependingon the patient's collaboration. However, this type of appliance does not prevent extrusion tooth and does not reestablish the masticatory function of the extracted tooth [19-24].

The authors suggest the use of this type of space maintainer because it presents advantages as being of low cost, easy installation and removal, good acceptance, not depending on patient collaboration, without interfering with phonation and mandibular growth, although presenting as a disadvantage not to prevent extrusion of the antagonist tooth following previous studies [19,21,22].

The interpretation of the results should consider some limitations inherent in this study. It is important that future studies be carried out on prevalence of early loss of deciduous tooth in posterior region and indication of band-loop space maintainer.

\section{CONCLUSION}

The prevalence of early deciduos molar loss was 4.04\%, from 568 children examined, being 15 in the lower arch and 8 in the upper arch of 23 children, mean age and standard deviation of $10 \pm 2$ years with predominance of the first deciduos molars, whose etiological factor was dental caries according to the parents or guardians.

The use of space maintainers after the early loss of a deciduous tooth is a preventive measure of malocclusion, being the band-loop appliance an excellent choice after loss of the deciduous unilateral molar. However, this method is effective when properly indicated and its execution technique rigorously followed.

\section{REFERENCES}

1. Almeida RR, Almeida-Pedrin RR, Almeida MR. Guidelines on the Use of Space Maintainers. Jornal Brasileiro de Ortodontia Ortopedia Facial. 2003;8(44):157-66.

2. Alencar CRB, Cavalcanti AL, Bezerra PKM. Early loss of deciduous teeth: etiology, epidemiology and orthodontic consequences. Publicatio. UEPG: Ciências Biológicas e da Saúde. 2007 marjun;13(1/2):29-37.

3. Araújo FM. Relationship between the type of breastfeeding and pacifier use 2002 mai-jun; 3(25): 235-40.

4. Tomita NE, Nilce E, Bijella VT, Franco LJ. Relationship between oral habits and malocclusion in preschool children. Rev Saúde Pública. 2000;34(3): 299-303.

5. Diniz MB, Silva RC, Zuanon ACC. Early dental loss and space maintenance in the deciduous dentition: report of a clinical case.JBP Revista Ibero-Americana de Odontopediatria \& Odontologia do Bebê. 2005;8(4):376-81.

6. Cardoso M, Rocha MJC. Esthetic space maintainer: a solution for traumatized primary teeth. Rev Ibero-am Odontopediatr Odontol Bebê. 2004 nov-dez; 7(40):512-18. .

7. Terlaje RD, Donly KJ. Treatment planning for space maintenance in the primary and mixed dentition. J. Dent. Child. 2001; 68(2):109-14.

8. Tagliaferro EPS, Guirado CG. Space maintenance after early loss of primary teeth. RFO UPF. 2002;7(2):13-7. doi:10.5335/rfo.v7i2.1222.

9. Cardoso L, Zembruski C, Fernandes DSC, Boff I, Pessin V. Evaluation of Prevalence of Precocious Losses of Deciduous Molars. Pesq Bras Odontoped Clin Integr. 2005;5(1):17-22.

10. Cavalcanti AL, Menezes AS, Granville-Garcia AF, Fontes LBC. Prevalence of early loss of deciduous molars: a retrospective study. Acta Sci Health Sci. 2008; 30(2):139-43. doi: 10.4025/actascihealthsci. v30i2.3943.

11. Peres MA, Traebert J, Marcenes W. Calibration of examiners for dental caries epidemiology studies. Cad Saúde Pública. 2001 janfeb;17(1):153-9. 
12. KorytnickI D, Naspitz N, Kurt Júnior F. Consequences and treatment of early loss of deciduous teeth. Rev Assoc Paul Cir Dent. 1994 mai-jun; 48(3):1323-9.

13. Kurame M, Magnani MBBA, Almeida MHC, Vedovelho SAS, Lucato AS. Early loss of deciduous teeth: etiology, consequences and clinical management. J Bras Odontopediatr Odontol Bebê. 2001 set-out; 4(21):411-8.

14. Galindo VAC, Péres TRM, Yamasaki E, Miranda DK, Nogueira JSE. Esthetic and functional space maintainer in the primary dentition. $\mathrm{J}$ Bras Odontopediatr e Odontol do Bebê. 2003 mar-abril;6(30): 99-104.

15. Cardoso CAB, Lourenço Neto N, Paschoal MAB, Silva SMB, Lima JEO. Oral rehabilitation in childhood: case report. Rev Odontológic de Araçatuba. 2011 jul-dez; 32(2):49-53.

16. De Souza RA, Magnani MBBA, Nouer DF, Romano FL, Passos MR. Prevalence of malocclusion in a brazilian schoolchildren population and its relationship with early tooth loss. Braz J of Oral Scienc. 2016; 7(25):1566-70.

17. Santos AGC, Machado CV, Telles PDS, Rocha MCBS. Early loss of deciduous molars in children assisted by the School of Dentistry of the University of Bahia. Odontol. Clín.-Cient. 2013 jul/set; 12 (3):189-93.
18. Costa-Silva CM, Jeremias F, Souza JF, Cordeiro RCL, Santos-Pinto L, Zuanon ACC. Molar incisor hypomineralization: prevalence, severity and clinical consequences in Brazilian children. Int J Paediatr Dent. 2010; 20(6):426-34.

19. Owen D.G. The incidence and nature space closure following the premature extraction of deciduous teeth: A literature survey. American Journal of Orthodontics. 1971;59(1):37-49.

20. Pokorná H, Marek I, Kucera J, Hanzelka T. Space reduction after premature loss of a deciduous second molar-retrospective study. JDMS. 2016;15(2):1-8.

21. Proffit WR, Bennett IC. Space maintenance, serial extraction and the general practitioner. Journal of American Dental Association. 1967; 74(3):411-9.

22. Silva FWGP, Stuani AS, Queiroz AM. The importance of maintaining space in pediatric dentistry. Odontologia Clínica- Científica. 2007;6(4):289-92.

23. Menegaz AM, Favetti M, Michelon D, Azevedo MS, Cost CT. Effectiveness of space maintainers in pediatric dentistry: a systematic review. RF0. 2015 may/aug; 20(2):252-7.

24. Simon T, Nwabueze I, Queis H, Stenger J. Space maintenance in the primary and mixed dentitions. J Mich Dent Assoc 2012; 94(1):38-40.

\section{Ana de Lourdes Sá de Lira}

(Corresponding address)

Universidade Estadual do Piauí. Faculdade de Odontologia

Rua Senador Joaquim Pires 2076 - Ininga.

CEP: 64049-590. Teresina - PI - Brasil.

E-mail: anadelourdessl@hotmail.com 